\title{
Thin-film lithium and lithium-ion batteries
}

\author{
J.B. Bates, N.J. Dudney*, B. Neudecker, A. Ueda, C.D. Evans \\ Oak Ridge National Laboratory, P.O. Box 2008, Oak Ridge, TN 37831-6030, USA
}

\begin{abstract}
Research over the last decade at Oak Ridge National Laboratory has led to the development of solid-state thin-film lithium and lithium-ion batteries. The batteries, which are less than $15 \mu \mathrm{m}$ thick, have important applications in a variety of consumer and medical products, and they are useful research tools in characterizing the properties of lithium intercalation compounds in thin-film form. The batteries consist of cathodes that are crystalline or nanocrystalline oxide-based lithium intercalation compounds such as $\mathrm{LiCoO}_{2}$ and $\mathrm{LiMn}_{2} \mathrm{O}_{4}$, and anodes of lithium metal, inorganic compounds such as silicon-tin oxynitrides, $\mathrm{Sn}_{3} \mathrm{~N}_{4}$ and $\mathrm{Zn}_{3} \mathrm{~N}_{2}$, or metal films such as $\mathrm{Cu}$ in which the anode is formed by lithium plating on the initial charge. The electrolyte is a glassy lithium phosphorus oxynitride ('Lipon'). Cells with crystalline $\mathrm{LiCoO}_{2}$ cathodes can deliver up to $30 \%$ of their maximum capacity between 4.2 and $3 \mathrm{~V}$ at discharge currents of $10 \mathrm{~mA} / \mathrm{cm}^{2}$, and at more moderate discharge-charge rates, the capacity decreases by negligible amounts over thousands of cycles. Thin films of crystalline lithium manganese oxide with the general composition $\mathrm{Li}_{1+x} \mathrm{Mn}_{2-y} \mathrm{O}_{4}$ exhibit on the initial charge significant capacity at $5 \mathrm{~V}$ and, depending on the deposition process, at $4.6 \mathrm{~V}$ as well, as a consequence of the manganese deficiency-lithium excess. The 5-V plateau is believed to be due to oxidation $\mathrm{Mn}$ of ions to valence states higher than +4 accompanied by a rearrangement of the lattice. The gap between the discharge-charge curves of cells with as-deposited nanocrystalline $\mathrm{Li}_{1+x} \mathrm{Mn}_{2-y} \mathrm{O}_{4}$ cathodes is due to a true hysteresis as opposed to a kinetically hindered relaxation observed with the highly crystalline films. This behavior was confirmed by observing classic scanning curves on charge and discharge at intermediate stages of insertion and extraction of $\mathrm{Li}^{+}$ions. Extended cycling of lithium cells with these cathodes at 25 and $100^{\circ} \mathrm{C}$ leads to grain growth and evolution of the charge-discharge profiles toward those characteristic of well crystallized films. (C) 2000 Published by Elsevier Science B.V.
\end{abstract}

Keywords: Solid-state thin-film battery; Lithium battery; Lithium-ion battery; $\mathrm{LiCoO}_{2} ; \mathrm{LiMn}_{2} \mathrm{O}_{4}$; Hysteresis

\section{Introduction}

Research on thin-film solid-state lithium batteries begun a decade ago at the Oak Ridge National Laboratory [1-4] has resulted in the development of practical thin-film rechargeable lithium and lithiumion batteries, and several companies in the US are

*Corresponding author. Fax: + 1-423-574-4143.

E-mail address: dudneynj@ornl.gov (N.J. Dudney). now moving toward production of these devices for application in consumer and medical electronics. The long cycle and shelf life of these batteries results from the properties of the glassy lithium phosphorus oxynitride ('Lipon') electrolyte [5,6] which is stable in contact with metallic lithium at potentials from 0 to nearly $5.5 \mathrm{~V}$ and has an acceptable conductance in thin-film form. Responding to the need for thin-film batteries that can tolerate heating to $250-260^{\circ} \mathrm{C}$ so they can be integrated into circuits using the solder 
reflow process, we have synthesized several inorganic anode materials $[7,8]$ that result in thin-film lithium-ion cells which are stable at these temperatures. Recently, we have investigated batteries with in situ plated lithium anodes [9] which deliver the high energies of lithium cells while, prior to the initial plating, also are not affected by the solder reflow conditions. Thin-film batteries have been important tools in our studies of thin films of lithium intercalation compounds, allowing us to investigate the electrochemical properties of the pure phases free of binders [1-4,10-14] and to perform in situ experiments such as X-ray diffraction [11] and X-ray absorption [15] as a function of the lithium concentration in these materials.

The purpose of this paper is to summarize the results of recent studies of lithium, lithium-ion, and lithium free thin-film cells with crystalline $\mathrm{LiCoO}_{2}$ cathodes and to briefly describe some of the interesting properties of nano- and microcrystalline films in the lithium manganese oxide system. Published results and work in progress on the structure and electrochemical properties of thin films of layered $\mathrm{Li}-\mathrm{Ni}-\mathrm{Mn}$ oxides $[13,14]$ and amorphous $[1,10]$ and crystalline $\mathrm{V}_{2} \mathrm{O}_{5}$ will not reviewed. The paper will conclude with a brief discussion of applications and the status of manufacturing scaleup.

\section{Experimental procedures}

A schematic drawing illustrating the layout of a thin film battery and a micrograph of a fracture cross-section are shown in Fig. 1. For our laboratory cells, the substrate is typically a $2.54 \times 1.27 \times 0.1$ $\mathrm{cm}$ thick polycrystalline alumina plate, but cells have been fabricated on silicon, metal foils, and plastics. For the latter two substrates, the batteries are quite flexible. The cathodes, which are deposited by rf magnetron sputtering of the parent compounds, are characterized using a variety of physical and chemical techniques prior to depositing the electrolyte. After depositing the lithium phosphorus oxynitride ('Lipon') electrolyte, the lithium anode is deposited by thermal evaporation to a thickness corresponding to three to four times overcapacity. The lithium-ion cells on the other hand typically are cathode heavy. Cells that are to be exposed to air in order to make in situ X-ray diffraction measurements or that are to be subjected to extended cycling at high rates are covered with a protective coating consisting of a multilayer of parylene and titanium. Details about film deposition and characterization can be found in several references and on our web page $[1-5,16]$.

\section{Results and discussion}

\subsection{Crystalline $\mathrm{LiCoO}_{2}$ : lithium, lithium-ion, and lithium free cells}

Polycrystalline films of $\mathrm{LiCoO}_{2}$ deposited by rf magnetron sputtering exhibited a strong preferred orientation or texturing after annealing at elevated temperatures [17-19]. For films thicker than about 1 $\mu \mathrm{m}$, more than $90 \%$ of the grains were oriented with their (101) and (104) planes parallel to the substrate and less than $10 \%$ with their (003) planes parallel to the substrate. For example, the comparison of the $\mathrm{X}$-ray diffraction pattern of a $4-\mu \mathrm{m}$ thick film with that of a powdered (random) sample (Fig. 2), shows that within the sensitivity of the measurement, none of the grains had their (003) planes oriented parallel to the substrate. As the film thickness decreased below $1 \mu \mathrm{m}$, the percentage of (003)-oriented grains increased until at a thickness of about $0.05 \mu \mathrm{m}$, $100 \%$ of the grains were (003) oriented [19]. These extremes in texturing were caused by the tendency to minimize volume strain energy for the thicker films and the surface energy for the very thin films [18]. The strain energy arises from the difference in thermal expansion between the $\mathrm{LiCoO}_{2}$ film and the substrate on heating to the anneal temperature.

Examples of discharge curves of a $\mathrm{Li}-\mathrm{LiCoO}_{2}$ battery are shown in Fig. 3. At low currents, the discharge capacity corresponds to about $0.5 \mathrm{Li}$ per $\mathrm{CoO}_{2}$ or $137 \mathrm{mAh} / \mathrm{g}$. The shift to lower potentials with increasing current is due to cell resistance. Although lithium ion diffusion should be much faster through cathodes with a high percentage of (101)and (104)-oriented grains than through cathodes with predominately (003)-oriented grains [18,19], it was not possible to verify this expectation because the resistance of most cells was independent of cathode thickness up to $3 \mu \mathrm{m}$ [19]. For cells with $1-\mathrm{cm}^{2}$ cathodes deposited below $70^{\circ} \mathrm{C}$, the average resist- 

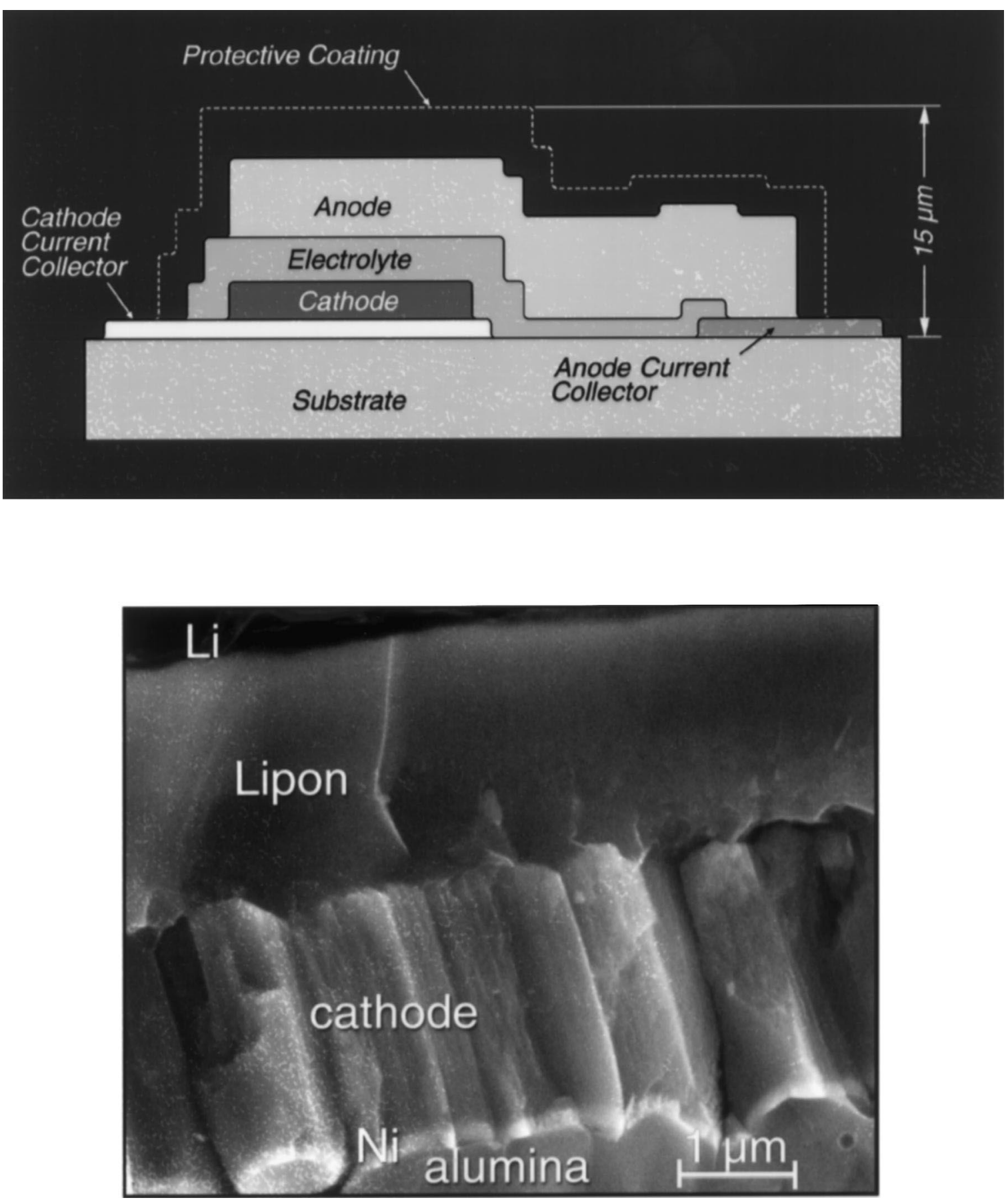

Fig. 1. Top: schematic cross-section illustrating the layout of a thin-film battery. Bottom: photograph of the fracture cross-section of a thin-film battery with a nanocrystalline as-deposited $\mathrm{LiMn}_{2} \mathrm{O}_{4}$ cathode fabricated on an alumina substrate. The apparent cracks in the Lipon electrolyte film and pullouts from the cathode and substrate were caused by fracturing. 


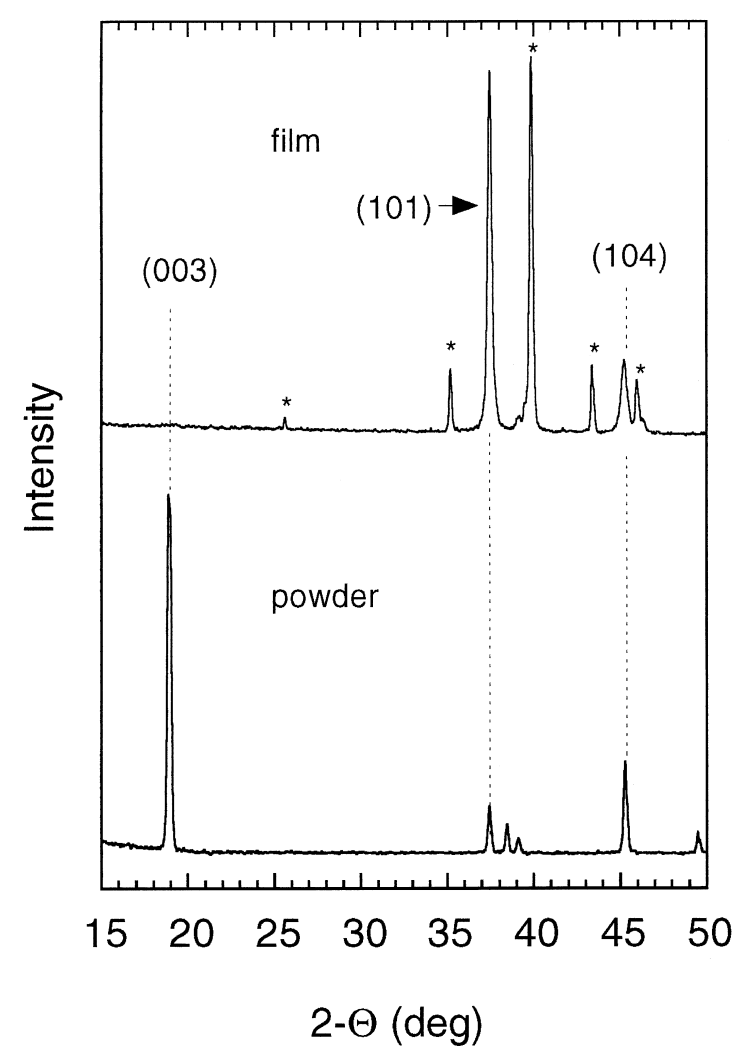

Fig. 2. X-ray diffraction patterns of a 4- $\mu$ m thick $\mathrm{LiCoO}_{2}$ film and a commercial powdered sample. Peaks marked with * are due to the alumina substrate. The absence of the (003) reflection and the strong intensity of the (101) reflection from the film indicate a high degree of preferred orientation. The grains of the powdered sample are presumed to be randomly oriented.

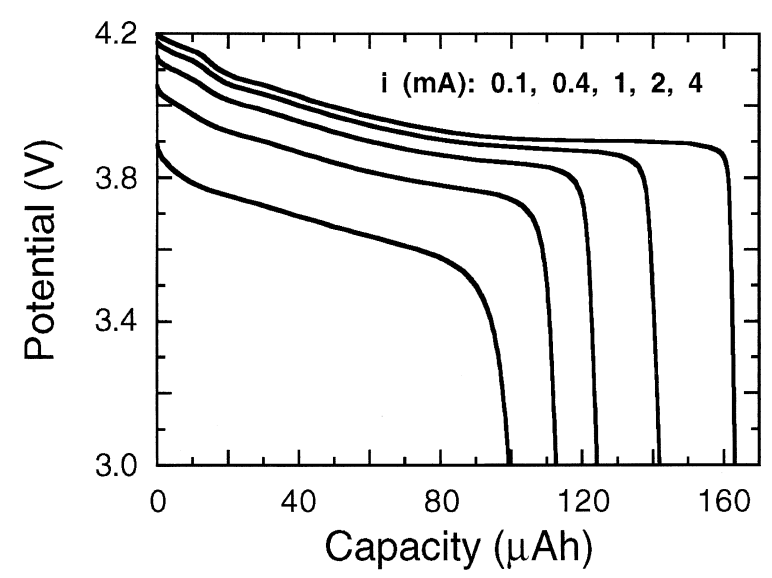

Fig. 3. Discharge of a lithium cell with a $1-\mathrm{cm}^{2} \times 2.5-\mu \mathrm{m}$ thick crystalline $\mathrm{LiCoO}_{2}$ cathode. ance of about $110 \Omega$ was due to the electrolyte and electrolyte-cathode interface. These cells could deliver significant fractions of their maximum capacity and energies at discharge rates of $5 \mathrm{~mA} / \mathrm{cm}^{2}$ or higher as illustrated by the graphs in Fig. 4. The most important process variable in achieving low resistance cathode films is the deposition temperature. Deposition at temperatures above about $100^{\circ} \mathrm{C}$ leads to larger grains and increased void fraction. This reduces the contact area between the electrolyte and cathode as well as the contact area between the grains resulting in higher cell resistances.

The secondary performance of thin-film lithium batteries is illustrated in the graphs of capacity versus cycle number in Fig. 5. The total capacity loss of the cell with the thinner cathode having a capacity of $65 \mu \mathrm{Ah}$ was less than $2 \%$ after more than 4000
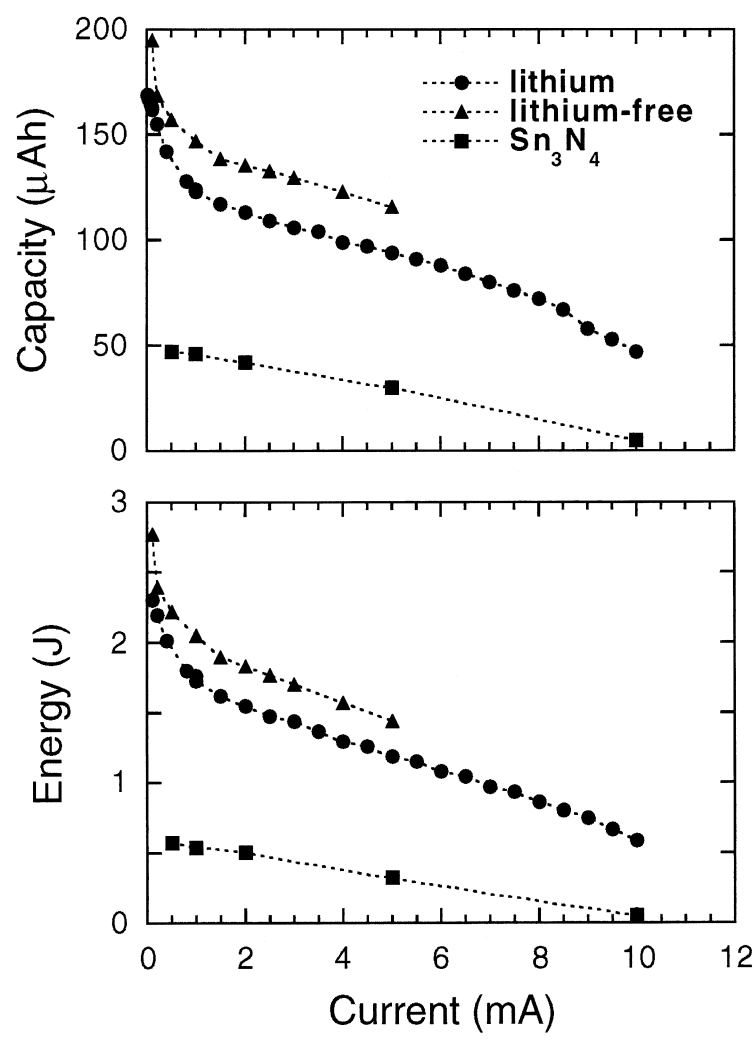

Fig. 4. Capacity and energy versus discharge current for cells with crystalline $1-\mathrm{cm}^{2}$ crystalline $\mathrm{LiCoO}_{2}$ cathodes. Lithium and lithium-free cells discharged between 4.2 and $3 \mathrm{~V}$; lithium-ion cell discharged between 4.2 and 2.7 V. Cathode thickness, 2.5, 3.2 and $0.9 \mu \mathrm{m}$, respectively for the lithium, lithium-free, and $\mathrm{Sn}_{3} \mathrm{~N}_{4}$ cells. 


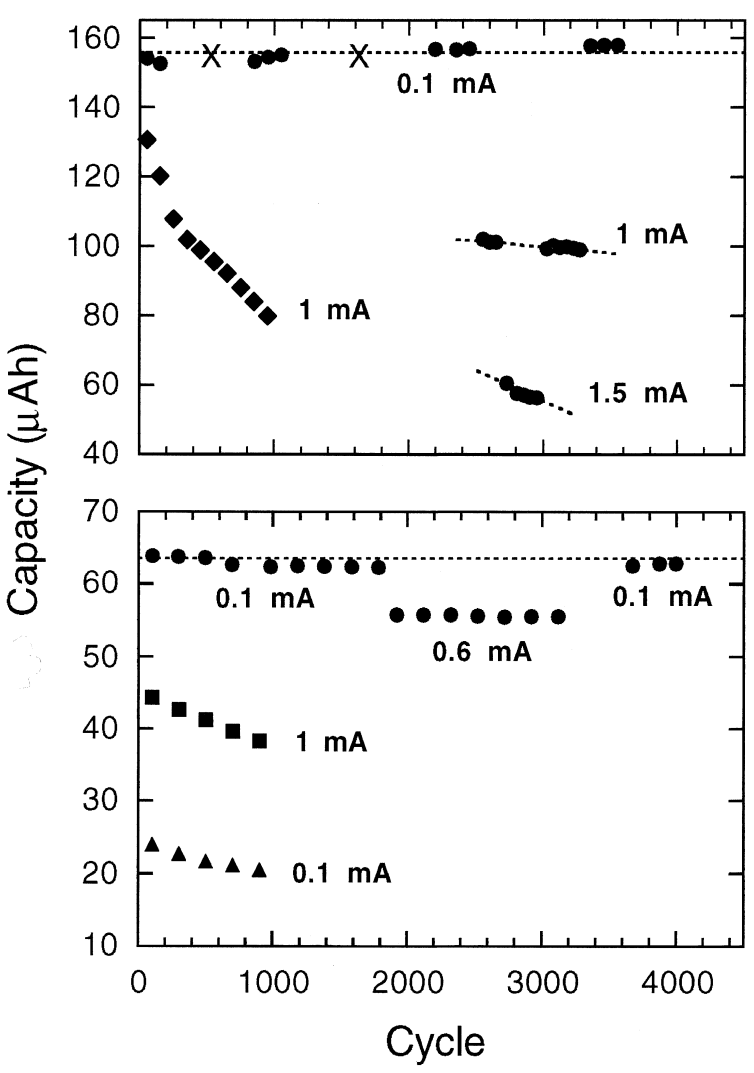

Fig. 5. Discharge capacity versus cycle number for lithium, lithium-free, and lithium-ion cells with $\mathrm{LiCoO}_{2}$ cathodes of different thickness cycled at different currents. (-) Lithium cells and (ם) lithium-free cells cycled between 4.2 and $3 \mathrm{~V}$; lithium-ion cells with $(\bullet) \mathrm{Sn}_{3} \mathrm{~N}_{4}$ and $(\boldsymbol{\Delta}) \mathrm{Zn}_{3} \mathrm{~N}_{2}$ anodes cycled between 4.2 and $2.7 \mathrm{~V}$. The cycle performance of cells with silicon-tin oxynitride anodes is similar to that of the $\mathrm{Sn}_{3} \mathrm{~N}_{4}$ cells. The dotted horizontal lines drawn through the data for the lithium cells emphasize the negligible capacity loss. Cycles in the gaps marked by ' $\mathrm{X}$ ' in the data for the $\mathrm{Li}$ cell given in the top panel were obtained at $0.2,0.4$ and $0.8 \mathrm{~mA}$ and are not shown for clarity.

cycles at discharge rates of 0.1 and $0.6 \mathrm{~mA}$. The cell with the thicker cathode was discharged at rates from 0.1 to $1.5 \mathrm{~mA}$. At $1 \mathrm{~mA}$, the capacity loss per cycle was $0.02 \%$ and at $1.5 \mathrm{~mA}, 0.05 \%$ per cycle. The total capacity loss measured at $0.1 \mathrm{~mA}$ after more than 3800 cycles was smaller than the experimental error or less than $0.08 \%$. Achieving a low capacity loss especially at high discharge rates requires that the lithium anode be covered with the protective parylene-titanium multilayer coating in order to prevent changes in the morphology of the anode evidently brought about by the combination of exposure of lithium to residual oxygen and the high rate of lithium plating and stripping.

Some integrated circuits are fabricated using solder reflow (surface mount) assembly in which the IC is heated to $250-260^{\circ} \mathrm{C}$ for a short time causing all of the components to be soldered at once. Because of the low melting point of lithium, $180^{\circ} \mathrm{C}$, lithium batteries fail when heated to these temperatures, and so we sought to replace the pure metallic anode with a high melting and less reactive inorganic compound. We have investigated several oxynitride [7] and nitride [8] compounds as possible anode materials. Low current discharge curves of $\mathrm{LiCoO}_{2}$ lithium-ion cells with silicon tin oxynitride, tin nitride, and zinc nitride anodes are compared in Fig. 6 with a discharge curve for a cell with a lithium metal anode. Silicon-tin oxynitride (SiTON) [7] with a typical composition $\mathrm{SiSn}_{0.87} \mathrm{O}_{1.20} \mathrm{~N}_{1.72}$ is deposited by sputtering $\mathrm{SnSiO}_{3}$ in $\mathrm{N}_{2}$ while tin and zinc nitride are deposited by sputtering of the base metals in $\mathrm{N}_{2}$. On the initial charge, $40-50 \%$ of the lithium is irreversibly trapped in the anodes by the formation $\mathrm{Li}_{2} \mathrm{O}$ and/or $\mathrm{Li}_{3} \mathrm{~N}$. Because of the lower discharge potentials and smaller capacities per unit area and thickness of the cathode, the energy delivered by lithium-ion cells is lower that of the lithium batteries. For example, the energy of the $\mathrm{Sn}_{3} \mathrm{~N}_{4}$ cell calculated from the curves in Fig. 6 is about $67 \%$ of that of the

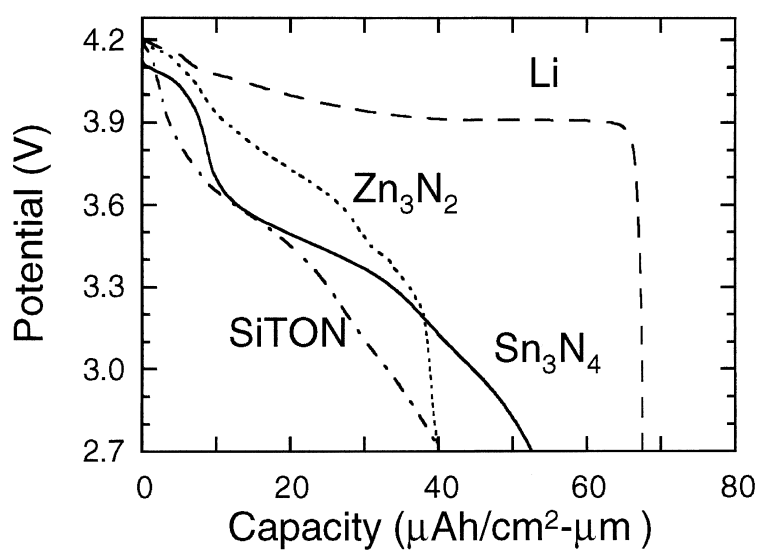

Fig. 6. Comparison of low current discharge curves of lithium-ion and lithium or lithium-free cells with crystalline $\mathrm{LiCoO}_{2}$ cathodes. Capacity in $\mu \mathrm{Ah}$ per unit of area in $\mathrm{cm}^{2}$ and thickness in $\mu \mathrm{m}$ of the cathode. 
lithium anode cell. However, in optimized $\mathrm{Sn}_{3} \mathrm{~N}_{4}$ cells in which lithium is plated on the anode during the charge step, the relative energy is increased to $83 \%$ [8]. More importantly, the lithium-ion cells are not affected by heat treatment at $250^{\circ}$ for times much longer than required for solder reflow, and they can deliver more than $50 \%$ of their maximum capacity and energy at discharge rates up to $5 \mathrm{~mA} / \mathrm{cm}^{2}$ (Fig. $4)$. The secondary performance of lithium ion cells with $\mathrm{Zn}_{3} \mathrm{~N}_{2}$ and $\mathrm{Sn}_{3} \mathrm{~N}_{4}$ anodes [8] discharged at 0.1 and $1 \mathrm{~mA} / \mathrm{cm}^{2}$, respectively, is illustrated in Fig. 5 . At $0.1 \mathrm{~mA}$, the capacity of the $\mathrm{Zn}_{3} \mathrm{~N}_{2}$ cell decreased by $27 \%$ over 1000 cycles while that of the $\mathrm{Sn}_{3} \mathrm{~N}_{4}$ cell discharged at $1 \mathrm{~mA}$ decreased by $43 \%$ over 1000 cycles.

Recently, we have fabricated [9] cells that exhibit the performance of thin-film lithium batteries, yet can tolerate the solder reflow conditions. In these cells, a metal current collector such as $\mathrm{Cu}$ is deposited over the electrolyte in place of the anode. On the initial charge, lithium from the $\mathrm{LiCoO}_{2}$ cathode is plated between the electrolyte and the $\mathrm{Cu}$ current collector as we have observed by viewing of a fracture cross-section in a scanning electron microscope during charge and discharge. Cycling then involves repeated stripping and plating of lithium under the $\mathrm{Cu}$. For cathodes of comparable thickness, the discharge curves of these 'lithium-free' lithium cells are identical to those for lithium anode cells such as those shown in Fig. 2. Before the initial charge, the 'lithium-free' cells can be heated to solder reflow temperatures without degrading subsequent performance. The graphs of capacity and energy versus current density for discharge between 4.2 and $3.0 \mathrm{~V}$ shown in Fig. 4 demonstrate that, as for the lithium cell, over $50 \%$ of the maximum capacity and energy is delivered at a current density of $5 \mathrm{~mA} / \mathrm{cm}^{2}$. An example of cycle data for a lithium-free cell is shown in Fig. 5. At a discharge current of $1 \mathrm{~mA} / \mathrm{cm}^{2}$, the capacity decreased by $20 \%$ over 1000 cycles.

The problem remaining to be solved before lithium-ion and lithium-free cells can be considered for applications is to reduce the percentage of cells that develop a leak on the initial charge, about $30-50 \%$ for both types. By comparison, the yield for cells with lithium anodes is over $90 \%$.

\subsection{Crystalline and nanocrystalline $\mathrm{LiMn}_{2} \mathrm{O}_{4}$}

The Li-Mn-O system is significantly more complex than $\mathrm{Li}-\mathrm{Co}-\mathrm{O}$ system as a consequence of the large number of phases and the wide variations in stoichiometry possible within the spinel structure [20]. We have deposited thin films by e-beam evaporation of $\mathrm{LiMn}_{2} \mathrm{O}_{4}$ and by rf magnetron sputtering of $\mathrm{LiMn}_{2} \mathrm{O}_{4}$ in $\mathrm{Ar}+\mathrm{O}_{2}$ and $\mathrm{Ar}+\mathrm{N}_{2}$. Postdeposition annealing of the nanocrystalline films in $\mathrm{O}_{2}$ at temperatures from 400 to $900^{\circ} \mathrm{C}$ yields well crystallized films with the spinel structure. The films are manganese-deficient-lithium-rich with compositions described by $\mathrm{Li}_{1+x} \mathrm{Mn}_{2-y} \mathrm{O}_{4}$, where the values of $x$ and $y$ depend on the deposition conditions. For example, for films sputter deposited in $\mathrm{Ar}+\mathrm{O}_{2}$, $y \sim 0.3$ and $0.2<x<1.2$.

Examples of low current discharge-charge curves for lithium cells with $\mathrm{Li}_{1+x} \mathrm{Mn}_{2-y} \mathrm{O}_{4}$ cathodes sputter deposited in $\mathrm{Ar}+\mathrm{N}_{2}$ and $\mathrm{Ar}+\mathrm{O}_{2}$ and annealed in $\mathrm{O}_{2}$ are shown in Fig. 7. Early in our investigations of lithium cells with e-beam deposited cathodes $[21,22]$, we found significant capacity at $5 \mathrm{~V}$ on the initial charge ranging from about 0.2 to $0.5 \mathrm{Li}$ per $\mathrm{Mn}_{2} \mathrm{O}_{4}$. The total capacity above $3.8 \mathrm{~V}$ corresponded to about one $\mathrm{Li}$ per $\mathrm{Mn}_{2} \mathrm{O}_{4}$. In a few cases, a plateau also was seen at $4.6 \mathrm{~V}$ which is so flat as to suggest that a two-phase reaction occurs at this potential. Following the initial charge, this plateau does not appear in subsequent cycles. The dashed line in Fig. $7 \mathrm{~b}$ shows a cycle from $4.5-1.5-5.3 \mathrm{~V}$ after 10 cycles between 3 and $5.3 \mathrm{~V}$. The disappearance of the $4.6-\mathrm{V}$ plateau was accompanied by an increase in the capacity at 4 and $3 \mathrm{~V}$ in the cubic-tetragonal twophase region. The $4.6-\mathrm{V}$ plateau is a major feature in the initial charge curves of annealed films sputter deposited at low rates in $\mathrm{Ar}+\mathrm{O}_{2}$ (10:1) (Fig. 7), but it is not seen in films deposited at higher rates in either $\mathrm{Ar}+\mathrm{N}_{2}$ or leaner $\mathrm{Ar}+\mathrm{O}_{2}$ mixtures (e.g. 50:1). We have found that the cathodes of those cells which exhibit the 4.6-V plateau contain monoclinic $\mathrm{Li}_{2} \mathrm{MnO}_{3}$ in addition to the cubic $\mathrm{LiMn}_{2} \mathrm{O}_{4}$ phase. Recently Shao-Horn et al. [23] reported that $\mathrm{Li}_{2} \mathrm{MnO}_{3}$ decomposes to $\mathrm{MnO}_{2}$ on acid delithiation. This suggests that in the thin-film cells, $\mathrm{Li}$ is extracted from $\mathrm{Li}_{2} \mathrm{MnO}_{3}$ during the initial charge causing decomposition and formation of $\mathrm{MnO}_{2}$ and, 

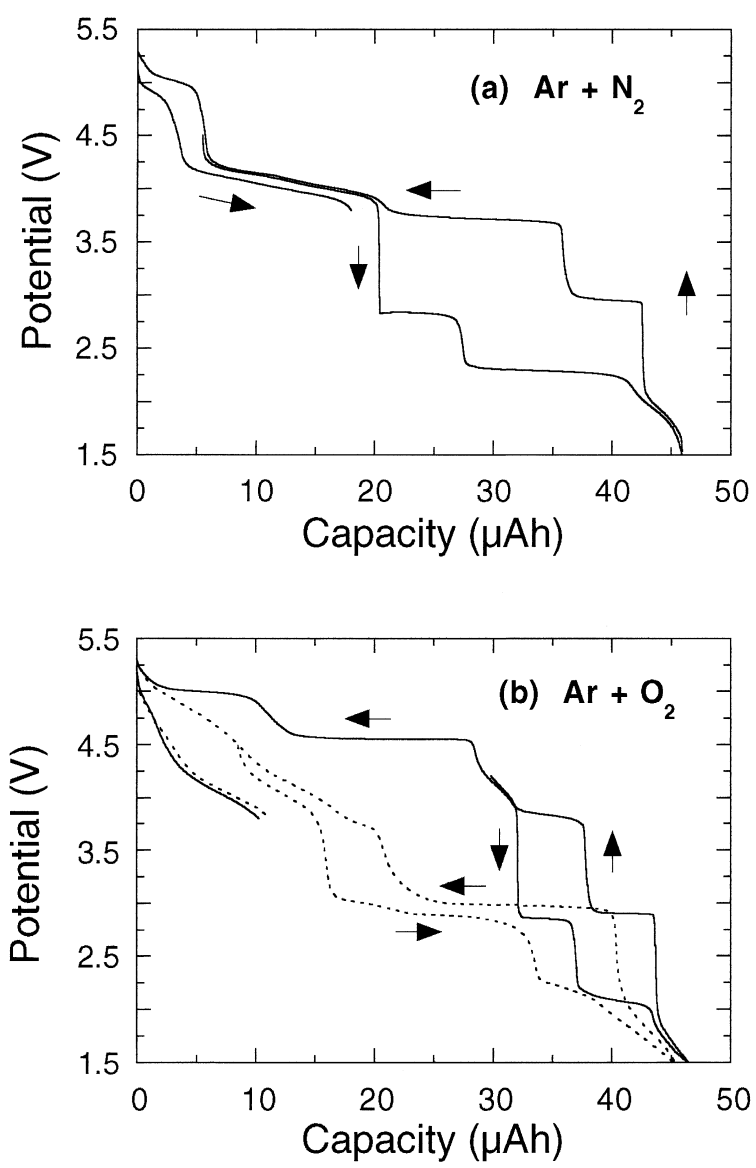

Fig. 7. Low current cycles of $\mathrm{Li}-\mathrm{Li}_{1+x} \mathrm{Mn}_{2-y} \mathrm{O}_{4}$ cells with cathodes sputter deposited in (a) $\mathrm{Ar}+\mathrm{N}_{2}$ and (b) $\mathrm{Ar}+\mathrm{O}_{2}$ and annealed in $\mathrm{O}_{2}$ at $700^{\circ} \mathrm{C}$ for $2 \mathrm{~h}$. Cycling sequence: (i) discharge from 4.5 to $1.5 \mathrm{~V}$; (ii) charge from 1.5 to $5.3 \mathrm{~V}$; and (iii) discharge from 5.3 to $3.8 \mathrm{~V}$. Dashed line in (b) is a discharge-charge cycle 4.5-1.5-5.3 $\mathrm{V}$ following 10 cycles between 5.3 and $3 \mathrm{~V}$.

possibly, $\mathrm{Li}_{2} \mathrm{O}$. On the subsequent discharge cycle, $\mathrm{Li}$ is inserted into the $\mathrm{MnO}_{2}$ formed by this reaction, $x \mathrm{Li}+2 \mathrm{MnO}_{2}=\mathrm{Li}_{x} \mathrm{Mn}_{2} \mathrm{O}_{4}$, increasing the capacity at 4 and $3 \mathrm{~V}$. However, there presently is no convincing evidence that $\mathrm{Li}_{2} \mathrm{MnO}_{3}$ is associated with the $4.6-\mathrm{V}$ plateau. The capacity of the $5-\mathrm{V}$ plateau also decreases on the discharge step following the initial charge (Fig. 7) and continues to decrease with subsequent cycles between 5.3 and $3.8 \mathrm{~V}$ as shown in Fig. 8. As shown in this figure, however, the lost capacity is partially recovered on the charge cycle after discharge to potentials of $2 \mathrm{~V}$ or lower.

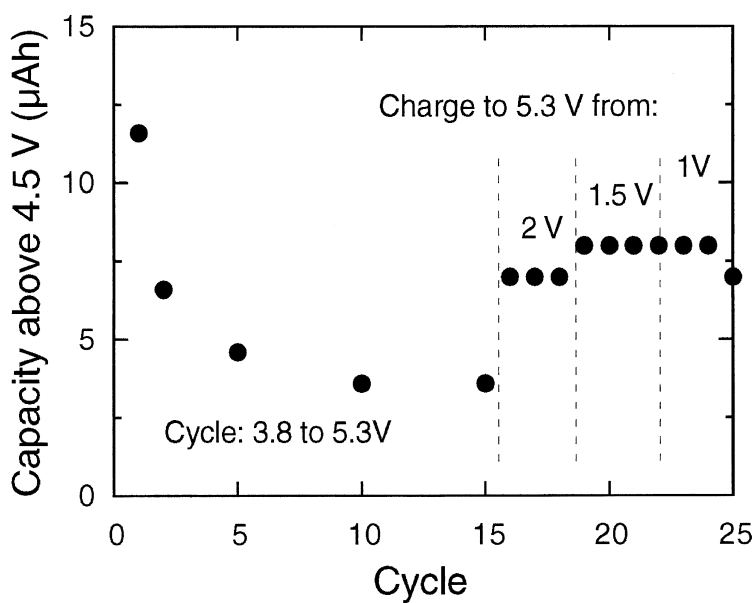

Fig. 8. Charge capacity above $4.5 \mathrm{~V}$ of a $\mathrm{Li}-\mathrm{Li}_{1+x} \mathrm{Mn}_{2-y} \mathrm{O}_{4}$ cell with cycling in different potential windows.

The appearance of the 4.6- and $5-\mathrm{V}$ plateaus is caused by the combination of the manganese deficiency and lithium excess of our sputter deposited films. Using a co-deposition process in which a second target of $\mathrm{Mn}$ was sputtered along with a $\mathrm{LiMn}_{2} \mathrm{O}_{4}$ target, additional $\mathrm{Mn}$ was added to the films with the result that capacity of the $5-\mathrm{V}$ plateau was greatly diminished (Fig. 9), and there was no

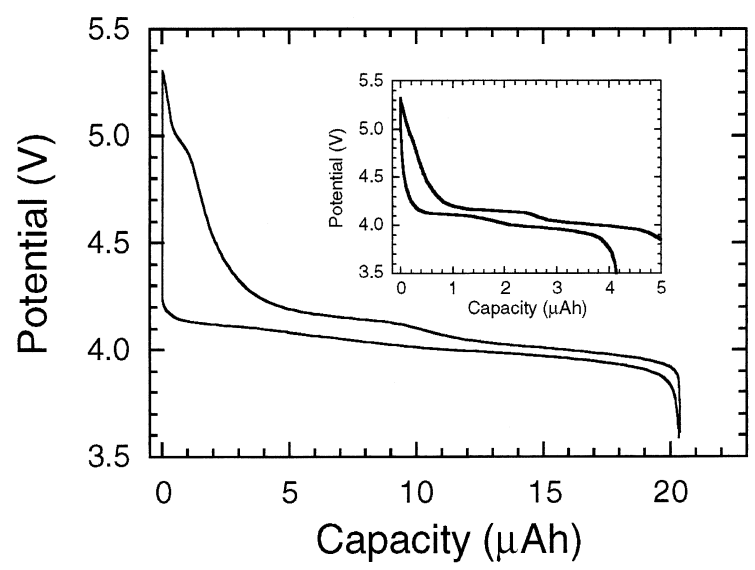

Fig. 9. Charge-discharge between 3.5 and $5.3 \mathrm{~V}$ of a lithium cell with a cathode deposited by co-sputtering $\mathrm{LiMn}_{2} \mathrm{O}_{4}$ and $\mathrm{Mn}$ in $\mathrm{Ar}+\mathrm{O}_{2}$ and annealing in $\mathrm{O}_{2}$ at $800^{\circ} \mathrm{C}$ for $2 \mathrm{~h}$. Inset: chargedischarge of a lithium cell with a $0.05-\mu \mathrm{m}$ thick cathode deposited over a $\mathrm{Au} / \mathrm{Mn}$ current collector by sputtering $\mathrm{LiMn}_{2} \mathrm{O}_{4}$ in $\mathrm{Ar}+$ $\mathrm{N}_{2}$ and annealing in $\mathrm{O}_{2}$ at $700^{\circ} \mathrm{C}$ for $2 \mathrm{~h}$. 
capacity at $4.6 \mathrm{~V}$. Typically we use a $0.03-\mu \mathrm{m}$ thick $\mathrm{Mn}$ layer under the $\mathrm{Au}$ or Pt current collector to improve adhesion of the cathode to the substrate. During the anneal in $\mathrm{O}_{2}$ at high temperatures, $\mathrm{Mn}$ diffuses through the metal overlayer into the $\mathrm{LiMn}_{2} \mathrm{O}_{4}$ film, and, with oxygen supplied by the cover gas, compensates for some of the $\mathrm{Mn}$ deficiency. The inset in Fig. 9 shows that for a 0.05$\mu \mathrm{m}$ thick $\mathrm{LiMn}_{2} \mathrm{O}_{4}$ film, there is no capacity at either 4.6 or $5 \mathrm{~V}$ as a result of the extra $\mathrm{Mn}$ from the current collector.

Several models have been proposed to account for the 5-V plateau. These are based on partially inverse spinel structures with some of the $\mathrm{Mn}^{4+}$ ions located on the $8 \mathrm{a}$ sites and some of the $\mathrm{Li}^{+}$ions on the $16 \mathrm{~d}$ sites [21,22], structures with $\mathrm{Li}^{+}$and $\mathrm{Mn}^{2+}$ ions on $16 \mathrm{c}$ sites in addition to the 8a and 16d sites [24], and the intergrowth of two spinel forms [25], one with the conventional structure $(\mathrm{Li})_{8 \mathrm{a}}\left[\mathrm{Mn}_{2}\right]_{16 \mathrm{~d}} \mathrm{O}_{4}$, and one with the $\mathrm{Li}$ and $\mathrm{Mn}$ ions occupying the alternative tetrahedral and octahedral sites, respectively $(\mathrm{Li})_{8 \mathrm{~b}}\left[\mathrm{Mn}_{2}\right]_{16 \mathrm{c}} \mathrm{O}_{4}$. From the results of chemical analyses for the $\mathrm{Li}$ and $\mathrm{Mn}$ content and Rutherford backscattering spectrometry that yielded the $\mathrm{Mn} / \mathrm{O}$ ratios, the average composition our films sputter deposited in $\mathrm{Ar}+\mathrm{N}_{2}$ and annealed in $\mathrm{O}_{2}$ at $700^{\circ} \mathrm{C}$ was $\mathrm{Li}_{1.4} \mathrm{Mn}_{1.8} \mathrm{O}_{4}$, or, assuming only $\mathrm{Mn}^{4+}$ and $\mathrm{Mn}^{3+}$ ions are present, $\mathrm{Li}_{1.4} \mathrm{Mn}_{1.2}^{4+} \mathrm{Mn}_{0.6}^{3+} \mathrm{O}_{4}$. When the cells are charged at $4.5 \mathrm{~V}, \mathrm{Li}^{+}$ions are extracted from the $8 \mathrm{a}$ sites as the $\mathrm{Mn}^{3+}$ ions are oxidized to $\mathrm{Mn}^{4+}$. Therefore, from the average composition, we expect a capacity at $4 \mathrm{~V}$ of $0.6 \mathrm{Li}$ per $\mathrm{Mn}_{2} \mathrm{O}_{4}$, in close agreement with experiment based upon the charge extracted and the mass of the cathodes estimated from the deposition rate and time. At the end of the $4.5 \mathrm{~V}$ charge, the average composition is $\mathrm{Li}_{0.8} \mathrm{Mn}_{1.8}^{4+} \mathrm{O}_{4}$, and on charging to $5.3 \mathrm{~V}$ approximately $0.4 \mathrm{Li}$ per $\mathrm{Mn}_{2} \mathrm{O}_{4}$ is extracted at $5 \mathrm{~V}$. One possible explanation for the $5-\mathrm{V}$ plateau is that further extraction of $\mathrm{Li}$ after complete oxidation of the $\mathrm{Mn}^{3+}$ results in the formation of holes in the $\mathrm{O} 2 \mathrm{p}$ valence band. However, because there is a one-to-one correlation between the shift to higher energies of the Mn-K edge X-ray adsorption spectra [15] with the concentration of Li extracted on charging from 1.5 to $5.3 \mathrm{~V}$, it is more likely the $5-\mathrm{V}$ plateau is due to oxidation of $\mathrm{Mn}^{4+}$ ions, perhaps to $\mathrm{Mn}^{5+}$. The rapid decrease in the $5-\mathrm{V}$ plateau with cycling between 5.3 and $3.8 \mathrm{~V}$ and the partial recovery of the capacity on discharging to potentials of $2 \mathrm{~V}$ or lower (Fig. 8) suggest that charging above $4.5 \mathrm{~V}$ induces a change in the lattice structure of the cathode which is partially reversed on discharge below $2 \mathrm{~V}$. Recent in situ X-ray diffraction measurements [11] are consistent with this speculation. At the present time, the data available are insufficient to distinguish among the defect models proposed for $\mathrm{Li}_{1+x} \mathrm{Mn}_{2-y} \mathrm{O}_{4}$ films and the oxidation processes that occur on charging above $4.5 \mathrm{~V}$. It is likely that refinement of neutron and X-ray diffraction measurements on bulk $\mathrm{Li}_{1+x} \mathrm{Mn}_{2-y} \mathrm{O}_{4}$ cathodes as a function of the lithium concentration at potentials from 1 to $5.3 \mathrm{~V}$ will be required in order to develop a credible model that is consistent with all of the data.

The capacity above $4.5 \mathrm{~V}$ in $\mathrm{Li}_{1+x} \mathrm{Mn}_{2-y} \mathrm{O}_{4}$ films can be stabilized by doping with $\mathrm{Ni}^{2+}$ ions [11]. We show in Fig. 10 the discharge curves for a film with $\mathrm{Ni} / \mathrm{Mn}=0.08 \quad( \pm 0.02)$ prepared by sputtering a $\mathrm{LiNi}_{0.1} \mathrm{Mn}_{1.9} \mathrm{O}_{4}$ target. There is a significant improvement in the capacity above $4.5 \mathrm{~V}$ compared to the undoped films (Fig. 7a), with the result that, for the same discharge current, the energy delivered by the cell is $20 \%$ higher than that supplied by a cell with an undoped $\mathrm{LiMn}_{2} \mathrm{O}_{4}$ film of equal thickness. On cycling between 5.3 and $3.8 \mathrm{~V}$, the total capacity decreased by less than $18 \%$ over 300 cycles (inset in

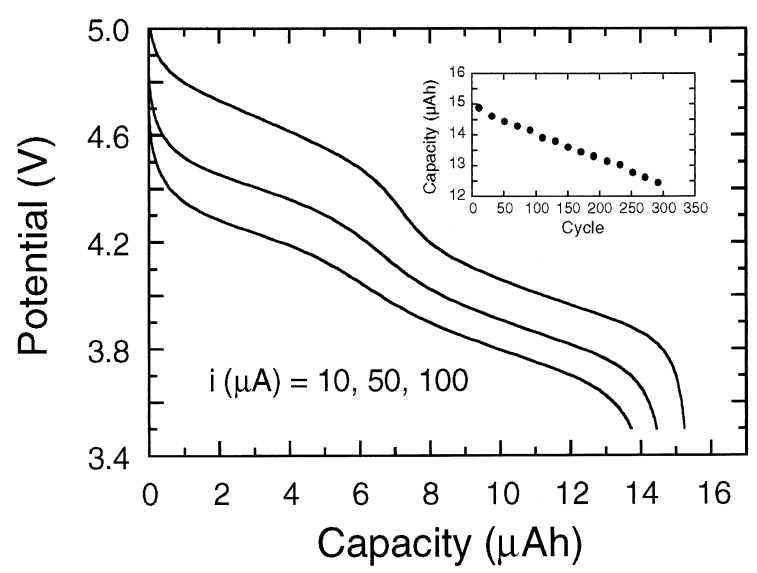

Fig. 10. Discharge of a lithium cell with a $1 \mathrm{~cm}^{2} \times 0.3 \mu \mathrm{m}$ thick Ni-doped $\mathrm{Li}_{1+x} \mathrm{Mn}_{2-y} \mathrm{O}_{4}$ cathode deposited by sputtering a $\mathrm{LiNi}_{0.1} \mathrm{Mn}_{1.9} \mathrm{O}_{4}$ target in $\mathrm{Ar}+\mathrm{N}_{2}$ followed by annealing the film in $\mathrm{O}_{2}$ at $700^{\circ} \mathrm{C}$. Inset: capacity vs. cycle number for discharge between $5.3 \mathrm{~V}$ and $3.8 \mathrm{~V}$ at a current of $10 \mu \mathrm{A}$. 
Fig. 10). Although it has been reported that substitution [26-29] of $\mathrm{Mn}$ with $\mathrm{Cr}, \mathrm{Fe}, \mathrm{Co}, \mathrm{Ni}$, and $\mathrm{Cu}$ in bulk $\mathrm{LiMn}_{2} \mathrm{O}_{4}$ increased the capacity above $4.5 \mathrm{~V}$, only $\mathrm{Ni}$ was found to enhance and stabilize the capacity above $4.5 \mathrm{~V}$ among the dopants introduced into the thin films which included $\mathrm{Ti}, \mathrm{V}, \mathrm{Cr}, \mathrm{Fe}, \mathrm{Co}$, $\mathrm{Ni}, \mathrm{Cu}$, and $\mathrm{Zn}$. Substituting some of the $\mathrm{Mn}$ with $\mathrm{Ti}$ increased the capacity at $4 \mathrm{~V}$ at the expense of the capacity at $5 \mathrm{~V}$.

The apparent hysteresis on cycling in the $3-\mathrm{V}$ spinel-tetragonal two-phase region (Figs. 7 and 11) is characteristic of all of our $\mathrm{LiMn}_{2} \mathrm{O}_{4}$ films $[21,22,30]$. Since the cell potential is a measure of
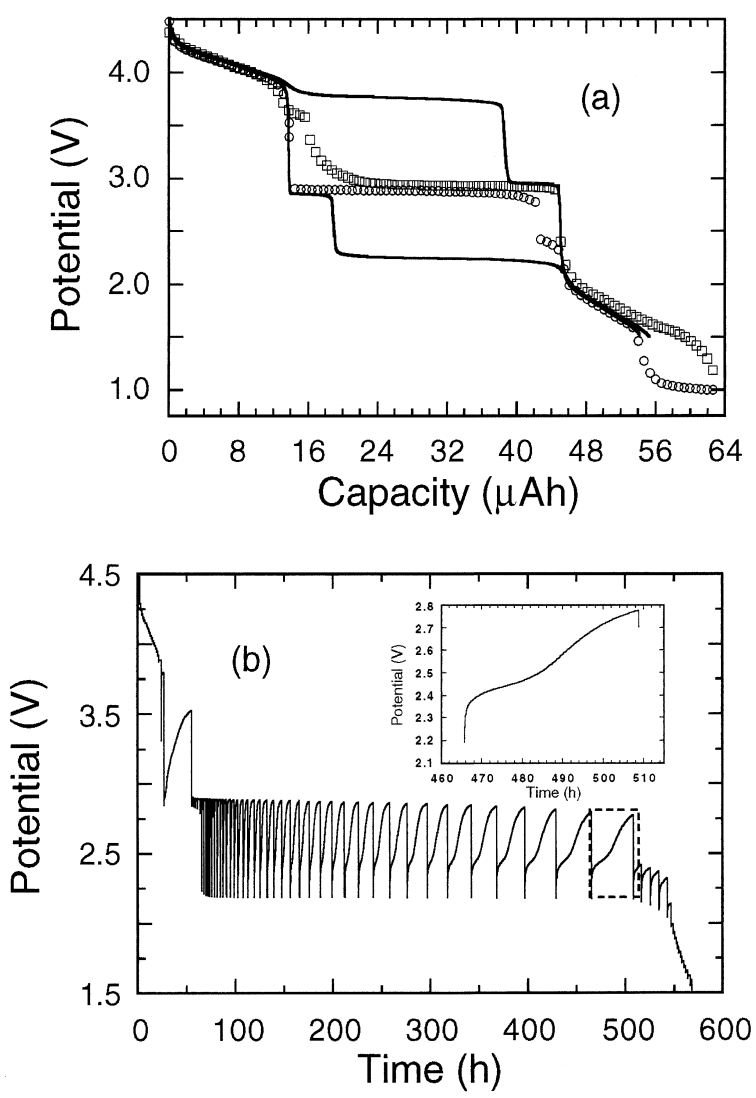

Fig. 11. Top: discharge-charge cycles of a $\mathrm{Li}-\mathrm{LiMn}_{2} \mathrm{O}_{4}$ cell between 4.5 and $1.0 \mathrm{~V}$. OCV data given by open circles (discharge) and squares (charge) are the potentials reached after relaxing until $\mathrm{d} V / \mathrm{d} t<5 \mathrm{mV} / \mathrm{h}$ following each $0.5 \mu \mathrm{Ah}$ of insertion or extraction of $\mathrm{Li}$. Bottom: potential versus time to reach the condition $\mathrm{d} V / \mathrm{d} t<5 \mathrm{mV} / \mathrm{h}$ after each insertion of 0.5 $\mu \mathrm{Ah}$ of Li. Inset shows the longest relaxation at the end of the two-phase region. the lithium activity in the cathode near the cathodeelectrolyte interface, the sudden step in potential from 3 to $2.5 \mathrm{~V}$ on discharge is caused by appearance of a new phase of $\mathrm{Li}_{1+x} \mathrm{Mn}_{2-y} \mathrm{O}_{4}$ at the interface. If the current is stopped, the potential relaxes to $3 \mathrm{~V}$ with a relaxation time that increases from a few hours to more than $40 \mathrm{~h}$ from the beginning to the end of the $3-\mathrm{V}$ region where the cathode is fully converted to the tetragonal phase (Fig. 11). On the charge half cycle, the sudden increase in potential from 3 to $\sim 3.8 \mathrm{~V}$ also is due to the formation of a third phase at the cathode-electrolyte interface, and the relaxation time increases in the same manner from the beginning to the end of the two-phase region where the cathode is fully converted to the spinel phase. Due to the simple geometry of the solid-state cell, $\mathrm{Li}^{+}$diffuses from one interface to another in a linear fashion, and we believe that the cycling behavior in the $3-\mathrm{V}$ region is due to nucleation at the cathode-electrolyte interface followed by phase boundary motion toward the cathode-current collector.

As-deposited $\mathrm{Li}_{1+x} \mathrm{Mn}_{2-y} \mathrm{O}_{4} \quad$ films are nanocrystalline, exhibiting weak, broad diffraction peaks in the $2 \theta$ regions of the (111), (311), and (400) reflections [12]. Examples of charge-discharge curves of a lithium cell between 4.5 and $1.5 \mathrm{~V}$ are shown in Fig. 12a. The sharp steps in the cell potential are reminiscent of the discharge-charge curves of the crystalline cathodes (Fig. 7). Analogous to the crystalline cathodes, the large potential gap between the discharge and charge curves near 80 $\mu \mathrm{Ah}$ is due largely to slow kinetics, as can be seen by noting the much smaller gap between the OCV curves. However, unlike the crystalline cathodes, the nanocrystalline films exhibit a true hysteresis [30] as opposed to slow relaxation kinetics as indicated by the large gap between the OCV charge and discharge curves above $3 \mathrm{~V}$. The gap remains virtually unchanged at $100^{\circ} \mathrm{C}$, and when the potential versus relaxation time curves are extrapolated to infinite relaxation times, the maximum difference in potential between the extrapolated charge and discharge curves is about $1 \mathrm{~V}$. Typical of a true hysteresis [31,32], scanning curves (Fig. 12b) show that the path between the charge and discharge curves on reversing the current depends on the starting point or cutoff voltage, and all points inside the hysteresis 

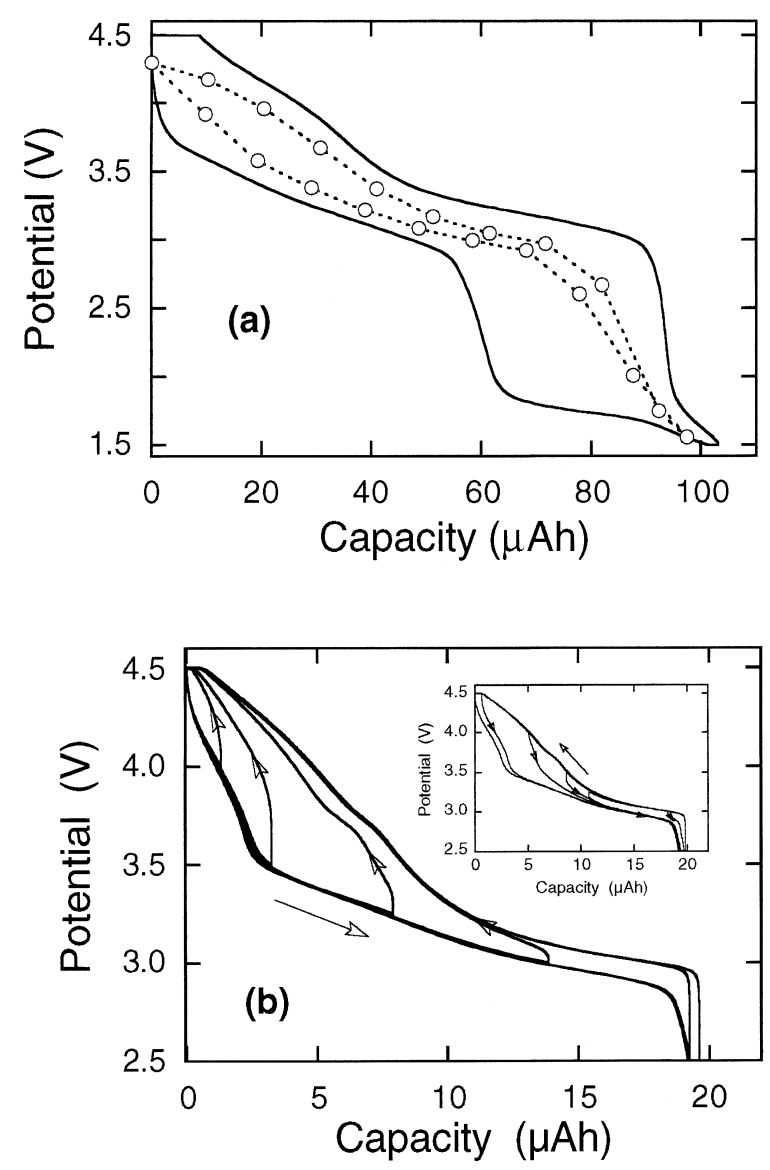

Fig. 12. (a) Low current discharge-charge (solid line) and OCV data (open circles) for a lithium cell with an as-deposited nanocrystalline $(n) \mathrm{Li}_{1+x} \mathrm{Mn}_{2-y} \mathrm{O}_{4}$ cathode. (b) Scanning curves for a $\mathrm{Li}-n \mathrm{Li}_{1+x} \mathrm{Mn}_{2-y} \mathrm{O}_{4}$ cell.

loop curves can be covered by a suitable choice of the starting point. We have observed similar behavior for as-deposited amorphous $\mathrm{V}_{2} \mathrm{O}_{5}$ cathodes and amorphous silicon tin oxynitride anodes. Hysteresis in solid-state systems is understood to occur to some extent for all first-order transitions at temperatures where the lattice mobility is small [33]. The effect is appreciable when the transformation requires a significant threshold driving force and occurs well away from equilibrium. This results in a dissipation of energy attributable to processes such as boundary motion, formation of dislocations, disordering, or plastic deformation. In order to describe real materials, it is often assumed that the material is composed of many independent 'domains' giving a distribution of values for the transformation thresholds.

Lithium cells with nanocrystalline $\mathrm{Li}_{1+x} \mathrm{Mn}_{2-y} \mathrm{O}_{4}$ cathodes have undergone extended cycling at 25 and $100^{\circ} \mathrm{C}$. As shown in Fig. 13a, the shape of the discharge curves gradually changed from the form characteristic of newly prepared cells to curves that closely resemble those for crystalline $\mathrm{LiMn}_{2} \mathrm{O}_{4}$. After many $100^{\circ} \mathrm{C}$ cycles, the discharge curves exhibit the characteristics of a well crystallized cathode including a plateau at $4 \mathrm{~V}$. This evolution of the shape of the discharge-charge curve was accompanied by a narrowing of the X-ray diffraction peaks as illustrated in Fig. 13b. These results suggest that extended cycling, especially at elevated tempera-
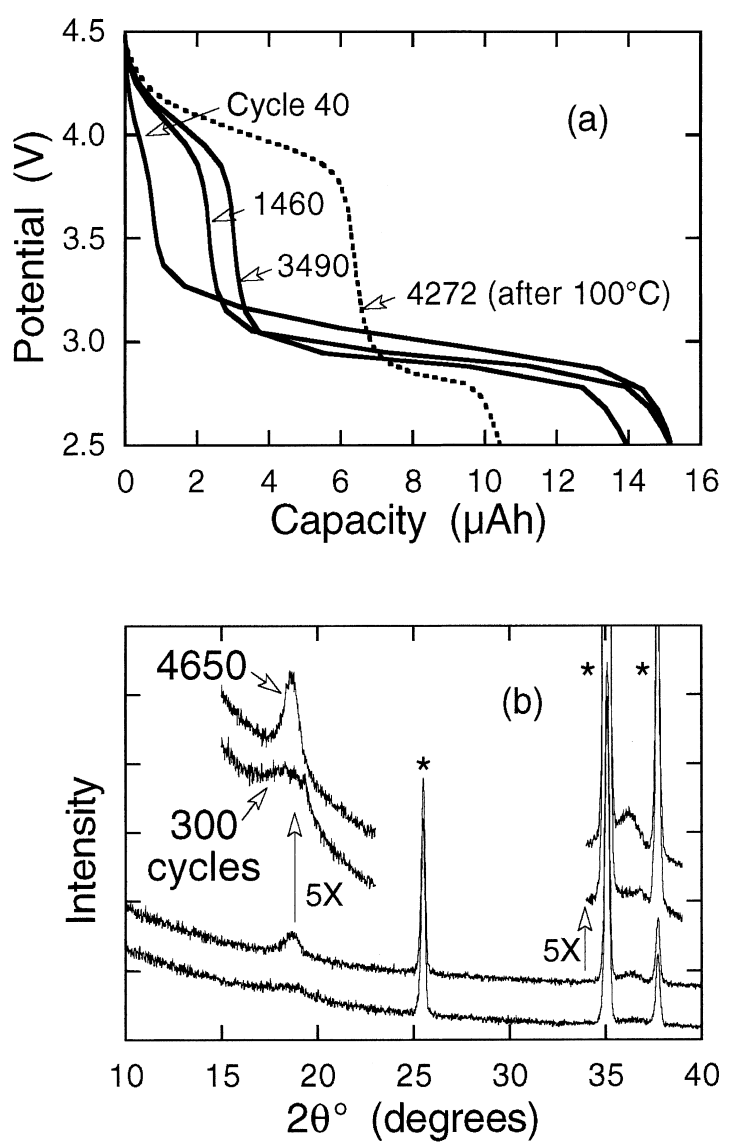

Fig. 13. (a) Discharge curves at $20 \mu \mathrm{A} / \mathrm{cm}^{2}$ for a $\mathrm{Li}-$ $n \mathrm{Li}_{1+x} \mathrm{Mn}_{2-y} \mathrm{O}_{4}$ cell after selected cycles at 25 and $100^{\circ} \mathrm{C}$; (b) in situ X-ray diffraction from this cell after cycles 300 and 4650. 
tures, promotes the growth of the nanocrystalline grains.

\subsection{Applications and commercialization}

The performance of thin-film solid state lithium and lithium-ion batteries makes them attractive for application in many consumer and medical products. Manufacturing scale-up is underway at several US companies, and at presently estimated production costs, the products targeted first for commercial application include implantable medical devices, CMOS-based integrated circuits, and rf identification tags for inventory control and anti-theft protection. The batteries will be incorporated as separate components, or they will be integrated into devices by direct fabrication on IC packages or chips. We show in Fig. 14 photographs of a stand alone prototype
'D'-shaped battery, a battery fabricated on a multichip module package, and a cell with a $1-\mathrm{cm}^{2}$ active area we use for our experiments. For high-power applications, it will be necessary to connect many thin-film cells in parallel. Recently, in collaboration with Dr Leo Kwak of Teledyne Electronic Technologies, scaling of battery performance with increasing active area was demonstrated by connecting $107.5 \mathrm{~cm}^{2}$ 'D'-shaped $\mathrm{Li}-\mathrm{LiCoO}_{2}$ cells in parallel giving a battery with a total active area of $75 \mathrm{~cm}^{2}$. The battery was required to supply on a single charge a minimum of five pulses of $2.5 \mathrm{~mA} / \mathrm{cm}^{2}$ amplitude, $8.5 \mathrm{~s}$ duration, followed by a 2 -s rest with a minimum of $60 \mathrm{~mJ} / \mathrm{cm}^{2}$ of energy per pulse. For $75 \mathrm{~cm}^{2}$, these requirements translate to a pulse amplitude of $187.5 \mathrm{~mA}$ and an energy of $4.5 \mathrm{~J}$ per pulse. As shown in Fig. 15, the battery supplied 12 pulses of the required amplitude and energy on a

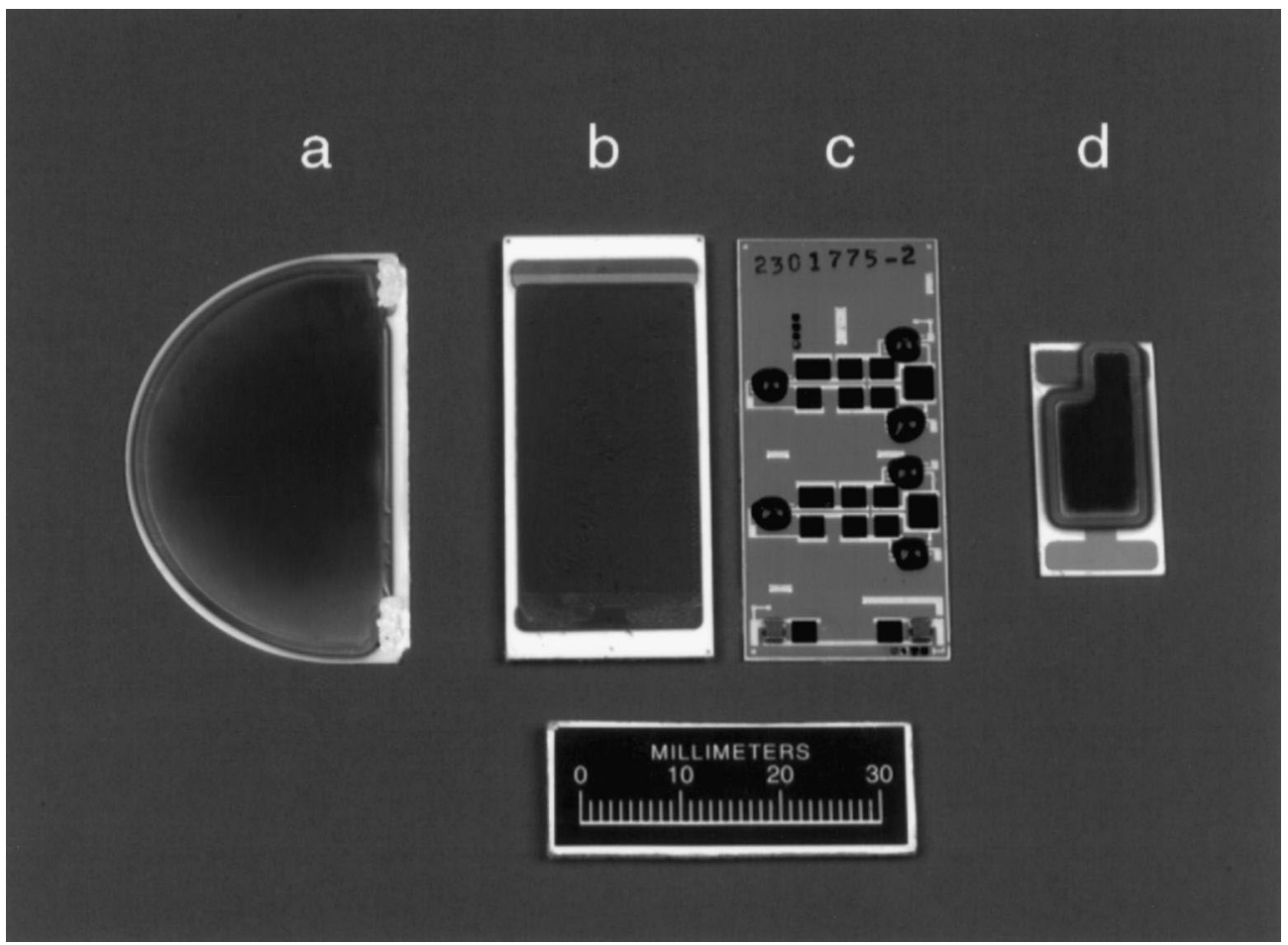

Fig. 14. Photographs of some of the prototype $\mathrm{Li}-\mathrm{LiCoO}_{2}$ thin-film batteries fabricated at ORNL. (a) ' $\mathrm{D}$ ' cell with a $7.5-\mathrm{cm}^{2}$ active area. (b) Battery with a $6.5-\mathrm{cm}^{2}$ active area fabricated on the backside of a multichip module package to power the circuit fabricated on the front side of the package shown in (c). Connection of the battery to the circuit was made by depositing the current collectors over gold coated through holes. (d) A typical experimental cell with a $1-\mathrm{cm}^{2}$ active area. 


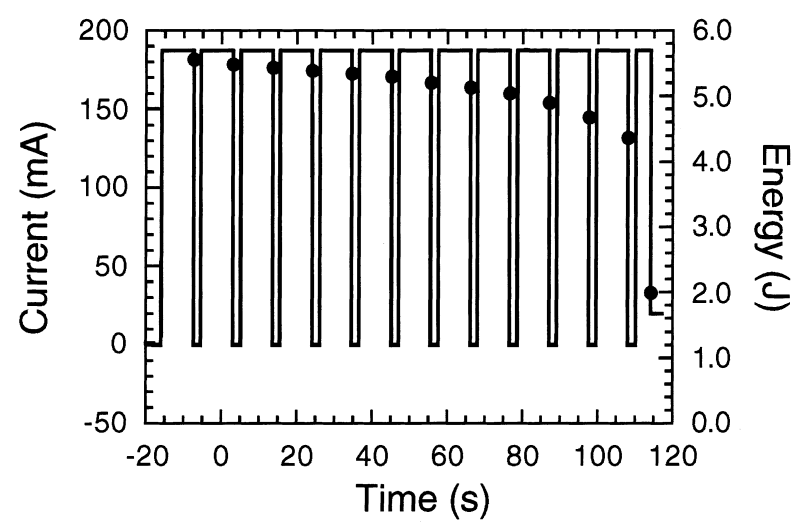

Fig. 15. Current pulses and total energy delivered by each pulse (solid points) for a $\mathrm{Li}-\mathrm{LiCoO}_{2}$ battery consisting of 10 cells, each with a $7.5-\mathrm{cm}^{2}$ active area, connected in parallel. The $187.5-\mathrm{mA}$ pulses were $8.5 \mathrm{~s}$ in duration and repeated every $2 \mathrm{~s}$ until the potential decreased below $2.5 \mathrm{~V}$.

single charge. Single laboratory cells with $1 \mathrm{~cm}^{2}$ active areas typically could supply $10-15$ pulses of the required current and energy densities.

There are many other possible applications of thin-film lithium and lithium-ion batteries in consumer products such as cellular telephones and notebook computers. The number and types of applications will be limited only by the cost of production.

\section{Acknowledgements}

The authors thank Mr Chris Luck and Mr Ivan Dunbar for fabricating many of the thin-film batteries discussed in this paper. Also, we gratefully acknowledge the support over many years by the US Department of Energy's Division of Materials Sciences, Division of Chemical Sciences, and Laboratory Technology Transfer Research Program under contract No. DE-AC05-96OR22464 with Lockheed Martin Energy Research Corp.

\section{References}

[1] J.B. Bates, N.J. Dudney, D.C. Lubben, G.R. Gruzalski, B.S. Kwak, X. Yu, R.A. Zuhr, J. Power Sources 54 (1995) 58.

[2] N.J. Dudney, J.B. Bates, D. Lubben, in: Role of Ceramics in Advanced Electrochemical Systems, American Ceramic Society, Westerville, OH, 1996, p. 113.
[3] B. Wang, J.B. Bates, F.X. Hart, B.C. Sales, R.A. Zuhr, J.D. Robertson, J. Electrochem. Soc. 143 (1996) 3203.

[4] J.B. Bates, N.J. Dudney, B.J. Neudecker, B. Wang, Thin-film lithium batteries, in: T. Osaka, M. Datta (Eds.), New Trends in Electrochemical Technology: Energy Storage Systems in Electronics, Gordon and Breach, 2000, p. 453.

[5] J.B. Bates, N.J. Dudney, G.R. Gruzalski, R.A. Zuhr, A. Choudhury, C.F. Luck, J. Power Sources 43-44 (1993) 103.

[6] X. Yu, J.B. Bates, G.E. Jellison, B.C. Sales, J. Electrochem. Soc. 144 (1997) 524.

[7] B.J. Neudecker, R.A. Zuhr, J.B. Bates, Lithium silicon tin oxynitride ( $\left.\mathrm{Li}_{y} \mathrm{SiTON}\right)$ : high performance anode in thin-film lithium-ion batteries for microelectronics, J. Power Sources 81-82 (1999) 27.

[8] B.J. Neudecker, R.A. Zuhr, in: Intercalation Compounds for Battery Materials, Proceedings of the Electrochemical Society (in press).

[9] B.J. Neudecker, N.J. Dudney, J.B. Bates, Lithium-free thinfilm battery with in-situ plated $\mathrm{Li}$ anode, J. Electrochem. Soc. 147 (2000) 517.

[10] B.S. Kwak, J.B. Bates, F.X. Hart, in: J.B. Bates (Ed.), Thin-Film Solid Ionic Devices and Materials, Electrochemical Society, Pennington, NJ, 1996, p. 137.

[11] A. Ueda, J.B. Bates, R.A. Zuhr, Lithium Batteries, Proceedings of the Electrochemical Society, Boston, Massachusetts, November 1-6, Vol. 98-16, 1999, pp. 279, 286.

[12] N.J. Dudney, J.B. Bates, R.A. Zuhr, S. Young, J.D. Robertson, H.P. Jun, S.A. Hackney, Nanocrystalline $\mathrm{Li}_{x} \mathrm{Mn}_{2-y} \mathrm{O}_{4}$ cathodes for solid state thin-film rechargeable lithium batteries, J. Electrochem. Soc. 146 (1999) 2455.

[13] B.J. Neudecker, R.A. Zuhr, B.S. Kwak, J.B. Bates, J.D. Robertson, J. Electrochem Soc. 145 (1998) 4148.

[14] B.J. Neudecker, R.A. Zuhr, J.D. Robertson, J.B. Bates, J. Electrochem. Soc. 145 (1998) 4160.

[15] M. Croft, D. Sills, J.B. Bates, P. Ansari, A. Alaya, A Mn-K edge XAS study of thin-film $\mathrm{Li}_{x} \mathrm{Mn}_{2} \mathrm{O}_{4}$ batteries, Phys. Rev. $\mathrm{B}$ (in press). 
[16] www.ssd.ornl.gov/BatteryWeb/

[17] J.B. Bates, N.J. Dudney, J. ASAIO 43 (1997) M644.

[18] F.X. Hart, J.B. Bates, J. Appl. Phys. 83 (1998) 7560.

[19] J.B. Bates, N.J. Dudney, B.J. Neudecker, F.X. Hart, H.P. Jun, S.A. Hackney, Preferred orientation of polycrystalline $\mathrm{LiCoO}_{2}$ films, J. Electrochem. Soc. 147 (2000) 59.

[20] M.M. Thackeray, A. de Kock, M.H. Rossouw, D. Liles, R. Bittihn, D. Hoge, J. Electrochem. Soc. 139 (1993) 363.

[21] J.B. Bates, D. Lubben, N.J. Dudney, F.X. Hart, J. Electrochem. Soc. 142 (1995) L149.

[22] J.B. Bates, D. Lubben, N.J. Dudney, R.A. Zuhr, F.X. Hart, in: J.B. Bates (Ed.), Thin Film Solid Ionic Devices and Materials, The Electrochemical Society, Pennington, NJ, 1996, p. 215.

[23] Y. Shao-Horn, Y. Ein-Eli, A.D. Robertson, W.F. Averill, S.A. Hackney, W.F. Howard Jr., J. Electrochem. Soc. 145 (1998) 16.

[24] M.M. Thackeray, M.F. Mansuetto, J.B. Bates, J. Power Sources 68 (1997) 153.

[25] M.M. Thackeray, J. Electrochem. Soc. 144 (1997) L100.

[26] T. Ohzuku, M. Iwanaga, S. Takeda, S. Kitano, in: 194th Meeting of the Electrochemical Society, Boston, Massachusetts, November 1-6, 1998, Abstract No. 121.
[27] H. Kawai, M. Nagata, H. Tukamoto, A.R. West, Electrochem. Solid-State Lett. 1 (1998) 212.

[28] S.Q. Zhong, A. Bonakdarpour, M. Zhang, Y. Gao, J.R. Dahn, J. Electrochem. Soc. 144 (1997) 205.

[29] Y. Ein-Eli, W.F. Howard Jr., S.H. Lu, S. Mukerjee, J. McBreen, J.T. Vaughey, M.M. Thackeray, J. Electrochem. Soc. 145 (1998) 1238.

[30] N.J. Dudney, J.B. Bates, C.D. Evans, F.X. Hart, Hysteresis in thin-film rechargeable lithium batteries, in: Processing and Characterization of Electrochemical Materials and Devices, Ceramic Transactions, American Ceramic Society, 2000, p. 341.

[31] D.H. Everett, W.I. Whitton, F.W. Smith, Trans. Faraday Soc. 48 (1952) 749.

[32] D.H. Everett, W.I. Whitton, F.W. Smith, Trans. Faraday Soc. 50 (1954) 187.

[33] T.B. Flanagan, C.-N. Park, W.A. Oates, Prog. Solid State Chem. 23 (1995) 291. 